\title{
Models of differentiated practice and specialization in community nursing: a review of the literature
}

\author{
Patrick G M Jansen MSc RN \\ Research Fellow, Department of Nursing and Canng Research, Netherlands Institute of \\ Primary Health Care (NTVEL), Utrecht, and Management Consultant, Hoeksma Homans \\ \& Menting, Enschede
}

\section{Ada Kerkstra PhD}

Senor Research Fellow, Department of Nursing and Carıng Research, Netherlands

Institute of Primary Health Care (NIVEL), Utrecht

Huda Huljer Abu-Saad PhD

Professor, Department of Nursing Scıence, University of Limburg, Maastmcht

and Jouke van der Zee $\mathrm{PhD}$

Professor and Director, Netherlands Institute of Primary Health Care (NIVEL), Utrecht, and Char of Primary Health Care Research, Department of Medical Sociology,

University of Limburg, Maastricht, The Netherlands

JANSEN P G M , KERKSTRA A , HUIJER ABU-SAAD H \& VAN DER ZEE J (1996)

Journal of Advanced Nursing 24, 968-980

Models of differentiated practice and specialızatıon in community nursing a review of the literature

In most agencies for community nursing at least two types of nurse are employed To ensure efficient use of personnel and high quality of nursing care, the principles of differentiated practice and specialization are used It is suggested that these types of work redesign will have consequences for nurses and their work We made a review of the literature to see how these principles are used and their effects on job satisfaction, burnout and quality of care This review provides several views and descriptions of nursing activities, but it also shows that there is a paucity of quantitative data about the effects of differentiated practıce and specialızation in community nursing To study these effects more systematically, a research model is presented This model makes it possible to describe the changes in job characteristics caused by differentiated practice and specialization Secondly, it allows the effects on job satısfaction, burnout and quality of care to be studied

\section{INTRODUCTION}

This article focuses on labour division in community nursing Because there is a difference among countries in the

Correspondence DrP GM Jansen, Tulpstraat 297555 BS Hengelo The Netherlands definition of 'community nursing', we begin by explauning what is meant by community nursing in this article Community nursing is restricted to the care provided at home by professional home nursing organizations It includes rehabilitative, supportive, promotive or preventive and technical nursing care The emphasis is maunly on the nursing of sick people at home Other possible 
community nursing activities are not included, e g preventive mother and child care, psychiatric care, midwifery, school health nursing and occupational nursing This means that for instance in the United Kingdom only distrnct nursing is considered

In several industrial countries at least two types of nurse are employed by community nursing agencies first level nurses and second level nurses This differentiation is based on a distunction in educational preparation (Verhey) \& Kerkstra 1992) Although both types of nurse have had a different type of training, this is often not expressed in nursing practice Due to uncertanty about demarcation, both types of nurse carry out largely identical duties For example, research in the Netherlands showed role amblguity between first level and second level community nurses in $41 \%$ of the agencies for community nursing (Jansen \& Kerkstra 1993) and Forsey et al (1993) state that there is perhaps as much as an $\mathbf{8 0} \%$ overlap between nursing roles in general Agencies for home health care are now also faced with changes The number of the elderly requiring home care is growing Technological change makes it possible to provide more complex nursing care at home, but this does require special expertise from the nurses At the same time, governments are also demanding a good price quality ratio in care (Turton 1984, Taylor 1985, Kenyon et al 1990, Gbbs et al 1991) Basic training is not always appropriate in meetıng the increases and changes in demand on community nursing

Under these circumstances, agencies delivenng community nursing care are forced to redesign nursing roles To ensure high quality of care and efficiency, two principles seem to be appropriate differentiated practice and specialization Differentuated practice is a personnel deployment model $\mathrm{in}$ which the roles of nurses are (re)defined based on education, experience and competence (Murphy \& DeBack 1990) Specialızation concerns the way in which specialized knowledge is avallable in the community in order to meet the changing and increasing complexity of home care

\section{THEORETICAL CONTEXT}

Differentiated practice and specialization are not issues restrncted to nursing alone In order to understand these prnciples from an organizational perspective, we shall first describe a central aspect of the division of labour job specialization This description is based on Mintzberg's (1983) Structure in Fives Designing effective organisations Organizations divide their labour (1 e specialıze) to increase productivity The reasons for increasing productivity are the improved dextenty of the worker from specialization in one job, the saving of time lost in switching jobs, and the development of new methods and machines that derive from specialization (Mintzberg 1983) These reasons are comparable with community nursing, where labour is divided to ensure high quality of care and efficient use of personnel

Jobs can be specialized in two dimensions The first is 'breadth' or 'scope' how many different tasks are there in each job and how broad or narrow is each of these tasks (horizontal job specialization deals with parallel activities) The second dimension of specialization relates to 'depth', to the control over the work This vertical specialization separates the performance of the work from its administration (Mintzberg 1983) By way of companson, in community nursing roles are specialızed vertically by 'differentiated practice' and horizontally by 'specialızation' In other words, with regard to differentiated practice, equivalent jobs are grouped at different levels based on the cost of labour criterion This results in different job descriptions containing activities which are equally rewarded The emphasis in specialization is on the quality of activities and the final result (Keuning \& Eppink 1990)

\section{Professional values}

When nursing roles are redesigned it is very important not to lose sight of professional values In line with this, Hackman \& Oldham $(1975,1976,1980)$ constructed the Job Charactenstics Model, specifically meant for work redesign (Figure 1)

This model posits the achievement of positive personal and work outcomes when three critical psychological states are present for a given employee (experienced meaningfulness of the work, experienced responsibility for outcomes of the work, and knowledge of the actual results of the work activities) These critical psychological states are created by the presence of five core job characteristics skill variety, task identity, task significance, autonomy and feedback (Hackman \& Oldham 1975, 1976, 1980) However, as the model as a whole was not validated in research, an altered version was used to describe hospital nursing practice (Landeweerd \& Boumans 1988, Boumans 1990) The intermediate role of the critical psychological states ( Algera et al 1986), and the effects of the moderators (Roberts \& Glick 1981, Boumans 1990) were not often val1dated Instead Boumans (1990) found direct relations between job and individual charactenstics and the outcome variables, eg job satisfaction, health complaints and quality of care Effects on depression, and psychological and psychosomatic complaints were also found (Algera

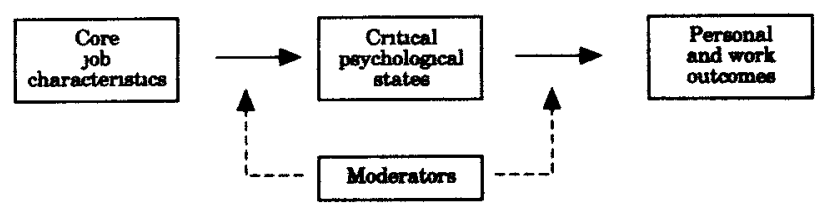

Figure 1 Job Characteristics Model

Source Hackman \& Oldham $(1975,1976,1980)$ 
1983, Broadbent 1985) These complaints can be grouped under the concept 'burnout', 'a syndrome of emotional exhaustion, depersonalization and reduced personal accomplishment that can occur among individuals who do people work of some knd' (Maslach \& Jackson 1986)

\section{Job Charactenstics Model}

Because of the link with work redesign, the Job Characteristics Model and the alterations made in other studies will be used as frame of reference for a review of the literature concerming differentiated practice and specialization

In line with this model the review of the literature seeks to address the following questions

1 What models are used to differentiate between nursing roles?

2 What models are used to make specialized knowledge available in community nursing?

3 What are the effects of differentiated practice and specialization on job charactenstics, job satısfaction, burnout and quality of care?

4 What aspects should be encompassed in a research model to evaluate the effects of differentuated practice and specialızation in community nursing?

\section{THE STUDY}

In order to obtain the international literature, searches were carried out in three computer databases MEDLINE (1986-94), Nursing and Allied Health Literature (only between 1992 and 1994, because of overlap with MEDLINE) and the Catalogue of the Netherlands Institute of Primary Health Care (NIVEL) (up to and uncluding 1995) The keywords used in these searches were (in alphabetical order) burnout, clinical ladder, clinical nurse specialist, differentuated practice, job satusfaction, level of expertise, nursing roles, quality of care, skall mix and specialization Because the literature found applied mainly to nursing in the USA, the United Kingdom and the Netherlands, the review was restricted to these countries Information about both hospital nursing and community nursing was reviewed to enable us to describe differentiated practice Hospital nursing was included because in the USA important examples were found in this area With respect to specialization, the review concentrates on community nursing alone as enough relevant examples were found The review does not claim to be exhaustive but representative

\section{RESULTS}

\section{Differentiated practice: the concept and models}

To differentiate between nursing roles, different models are used in the USA, the Netherlands and the United
Kingdom. Table 1 shows an overview of the models used, the types of nurse concerned and the means used for differentiatung nursing roles This figure will be illustrated by means of a description of the literature reviewed

In 1965, the American Nurses' Association proposed two levels of education, a baccalaureate degree for the professional nurse and an associate degree for the technical nurse (Hickey et al 1991) This proposal was the foundation for the model of differentiated practice used to differentiate between two nursing roles in hospitals based on education, experience and competence (Primm 1986, 1987, 1988, 1990, Koerner et al 1989, Amencan Organization of Nurse Executives 1990, Koerner 1990, Malloch et al 1990, McClure 1991, Hickey et al 1991, Forsey et al 1993) In the USA all registered nurses hold the same license to practice nursing regardless of their educational or expenentral background (Murphy \& DeBack 1990) To uthlize avalable nursing personnel more effectively, differentiated practice is applied Based on the premise that individual practitioners with different types of education, competence, and experience should not be used interchangeably, differentiated practice seeks to ensure that the work of nurses is carried out by the most appropriate nurse in the most appropriate way (Boston 1990)

The Sioux Valley Hospital/South Dakota Experience (Primm 1987, Koerner et al 1989, American Organization of Nurse Executives 1990) has been an important example for implementation of differentiated practice in nursing This project (1982-87) used a group process approach to achieve representative regional consensus on competencybased statements of practice expectation for diploma/ associate- and baccalaureate-prepared nurses The term 'competency-based' referred to identification of role behaviours by observation of the practice of 'experts' in the role In other words, the descriptions of practice are descriptions of 'competent' practitioners Based on these competencies two nursing roles were defined (Table 2)

The basic distunctions between the two roles with respect to differentuated practice centre on complexity of decision-making, tumeline of care and structure of situation and/or setting The baccalaureate nurse provides durect care to patients and therr famlies with complex interactions of nursing diagnoses from pre-admission to post-discharge in structured and unstructured settungs and situations The associate nurse provides direct care to pattents and members of the famuly with common, welldefined nursing diagnoses for a specified work penod in structured settings and situations (Primm 1986, Malloch et al 1990)

Although 'complexaty' is mentioned specifically in the job descriptions this dimension has not generally been included in American patent classification systems except to the degree that more complex care is often posituvely related to tume However, findings from the use of the 
Table 1 Models for differentiating nursing roles

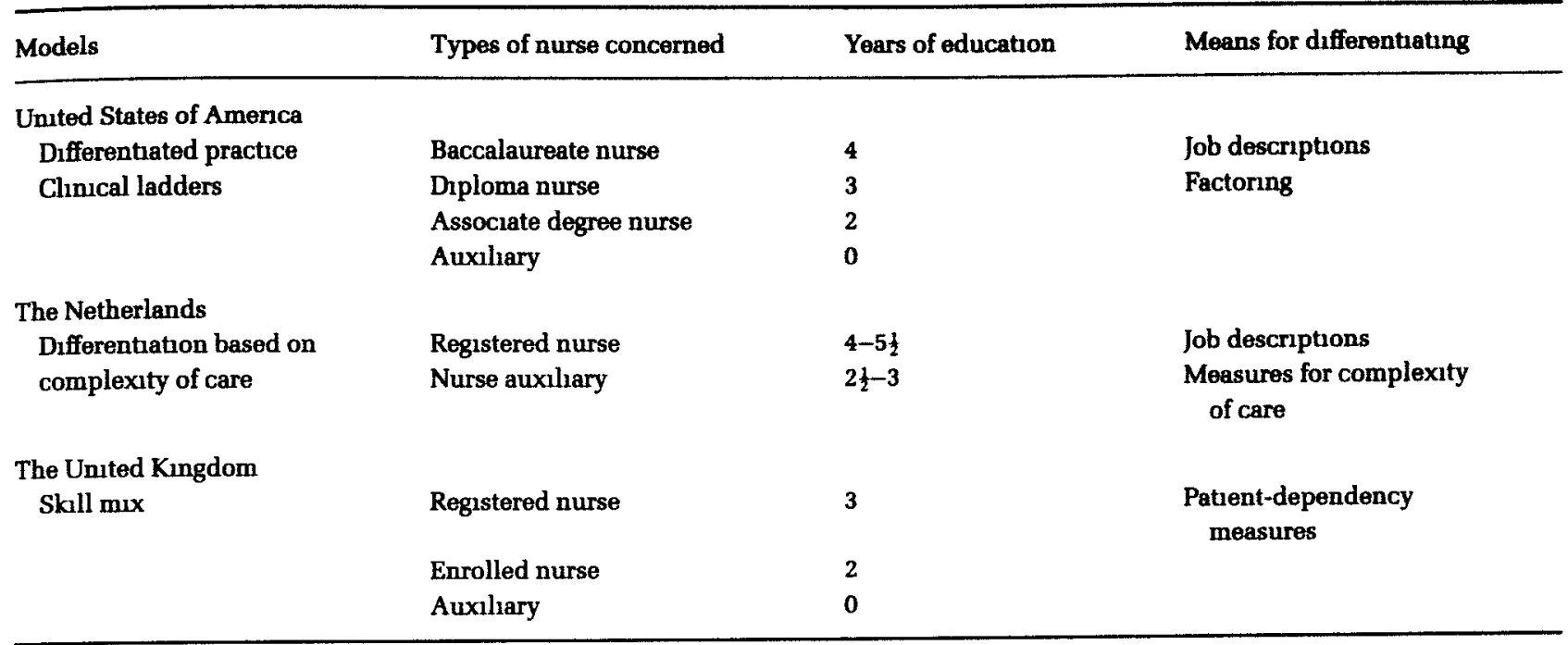

Table 2 Roles of the Associate Degree Nurse and the Baccalaureate Degree Nurse

Role of the Associate Degree Nurse (ADN)

The ADN is a licensed registered nurse who provides direct care that is based on the nursing process and focused on individual clients who have common, well-defined nursing diagnoses Consideration is given to the client's relationship within the family The ADN functions in a structured health care setting that is a geographical or situational environment where the policies, procedures, and protocols for provision of health care are established In the structured settung there is recourse to assistance and support from the full range of nursing expertise

The ADN uses basic communication skills with focal clients and co-ordunates with other health team members to meet focal clients' needs The ADN recognizes the individual's need for information and modifies a standard teaching plan The ADN recognizes that nursing research influences nursing practice and assists in standardized data collection

The ADN organizes for focal clients those aspects of care for which s/he is responsible The ADN maintains accountability for own practice and for aspects of nursing care s/he delegates to peers, licensed practical nurses, and ancillary nursing personnel Within a specified work period, the ADN plans and implements nursing care that is consistent with the overall admission to post-discharge plan The ADN practises within accepted ethical and legal parameters of nursing
Role of the Baccalaureate Degree Nurse (BSN)

The BSN is a licensed registered nurse who provides direct care that is based on the nursing process and focused on clients with complex interaction of nursing diagnoses Clients include individuals, families, groups, aggregates, and communities in structured and unstructured health care settungs The unstructured settung is a geographical or a situational environment that may not have established policies, procedures, and protocols and has the potential for variations requiring independent nursing decisions The BSN uses complex communication skalls with focal clients The BSN collaborates with other health team members and assumes an accountable role in change The BSN assesses the need for information and designs comprehensive teaching plans individualized for the focal client. The BSN collaborates with nurse researchers and uncorporates research findings into nursing practice The BSN manages comprehensive nursing care for focal clients The BSN mantauns accountability for own practice and for aspects of nursing care delegated to other nursing personnel consistent with their levels of education and expertıse The BSN plans for nursing care based on identıfied needs of the focal client from admission to post-discharge The BSN practises within accepted ethical and legal parameters of nursing

Source Prumm (1987), American Organization of Nurse Executives (1990)

Patient Intensity for Nursing Index (PINI) suggest that complexity of patient care needs are as, or more, important to the consumption of nursing resources than are patients' dependency needs (Soeken \& Prescott 1991) In only a few artucles was attention pard to the operationalization of the concept of 'complexity' According to Corcoran (1986), complexity is determined by the number of problems presented by the patient, the interrelation of the problems, and the extent to which protocols could be applied Verran \& Reid (1987) found that complexity was affected by the 
number of analyses that had to be performed, the variability of chents presenting to a clinic and the knowledge of a client (1 a nurse's understanding) Nursing care is considered complex when the degree of routıneness, uniformuty and predictability is low and special knowledge 18 necessary to deliver care The critical determinant of complexity is the extent to which knowledge is required to effectively apply interventions in the delivery of nursing service In addition, complexity involves not only the frequency of task performance but also knowing whether the procedures for its accomplishment are well-known and understood (Verran \& Re1d 1987)

In an effort to recognize and use the abilities of each nurse, the Sioux Valley Hospital chose 'factoring' as the mechanism to place nurses into their respective role categones Factoring involved self-assessment carmed out by each nurse using a factoring tool The head nurse also completed an assessment of each individual During a 1-hour intervew, the staff nurse and head nurse shared their assessments, observations, and goals for the project Registered nurses on each unit were factored into the ADN (Case Associate) or BSN (Case Manager) job description in collaboration with their head nurse A mutual decision for placement was reached (Koerner 1988)

Another model enabling differentiation between nursing roles is a chnical ladder programme In contrast with differentiated practice, 'expenence' is the only differentuatung factor here Clinical ladders were developed in the early 1980 s to cope with nurse recruitment and retention problems Current interest in these programmes is driven to retain experienced nurses who can improve quality Retaining clinically competent nurses requires an appropriate salary and a work envronment to support nurse autonomy A clincal ladder is one means of uncreasing avalability of these factors (Corley et al 1994) The conceptual basis for many clinical ladder programmes is Benner's (1984) work From novice to expert In it she describes five levels of practitioner, namely, novice, advanced beginner, competent, proficient and expert $A$ clinical ladder based on this can be constructed identIfying five levels of clinical nursing Subsequently, a review board determines the promotion of nurses on the clinical ladder based on a portfolio of their professional abilities and accomplishments On advancement to a new level, the nurses meet with the nurse manager to negotiate a new role (Corley et al 1994) Martin \& McGure (1990) described a three-level system used for the community health care setting The job descriptions within this system included behavioural descriptors of group process skalls, communication skalls, job skall knowledge, professional development expectations, meeting requirements, record keeping, and co-ordmation skill expectations (Martin \& McGurre 1990)

\section{Unlicensed personnel}

In principle, differentrated practuce and clinical ladders in Amencan nursing concern licensed personnel only However, because of a shortage of nurses and increased emphasis on cost contanment, registered nurses must adjust to the remtroduction of unlicensed assistıve personnel, also called nurse extenders or nurse assistants, into patient care areas (Barter \& Furmidge 1994) The use of unlicensed personnel leads to a major change in registered nurse focus from workng primarily as sole practitioner to functioning as managers of patient care, responsible for the direction and supervision of assistant staff (Jung et al 1994)

\section{The Netherlands community nursing agencies}

In the Netherlands community nursing agencies use a model that is to a large extent comparable with the American model of differentuated practice used in hospitals (Table 2) Because this model is described extensively above, only specific differences will be described here In the Netherlands differentiation is made between community nurses (first level, comparable with the BSN) and community nurse' auxilıanes (second level, comparable with the ADN) This differentiation is in line with the Dutch 'Nursung Profile' and based on education, responsibility and complexity of care (National Councll for Health Care 1988) In several agencies these general job descriptions are made applicable to community nursing in which distinction is made between junior and senior professionals (Vrielink 1990) The distinction between junior and senior can be interpreted as deriving from Benner's previously mentioned model to enable differentiation between nurses based on expenence In addition to the agencies for community nursing, differentiated practice is also implemented in hospitals In most hospitals a distunction is made by emphasizing supervision and co-ordination of care in the role of the first level nurse (Nationaal Ziekenhussinstituut - AortA 1994)

Within the Dutch job descriptions, special attention is pard to responsibility and complexity of care The complexity concept is more extensively used here than it is in the USA To decide whether or not nursing care is complex different measures have been developed in the Netherlands and are used in community nursing (Wijdeven 1989, Nollen 1990, Vnelınk 1990, Lapré \& Rutten 1989, Hanrahan \& Lapré 1990, Derckx et al 1993, van Amelsvoort et al 1993, Jansen \& Kerkstra 1993, Mostert 1993, van Til et al 1994) Based on an analysis of several nursing models by Fawcett (1989), Jansen \& Kerkstra (1993) constructed a measure in which critena for complexaty were dinded into four categories person (recipient of nursing actions), environment (recipient's significant others and the setting), health status (well and/or ill) and nursing activities Examples of criteria that determine the complexaty are the patient's willingness to 
co-operate (person), the number of disciplines involved in the care-situation (environment), the presence of informal carers able to cope with the situation (environment), the exastence of well-defined nursing diagnoses (health), the number of changes in the patient's health-status and the requirement for specific technological activities (nursing activities) If a patient needs complex nursing care a community nurse has to be assigned

\section{United Kingdom}

In the United Kingdom three types of nurse are employed in district nursing registered nurses, enrolled nurses and auxilianes Compared with the Amencan situation in the United Kingdom the registered nurse fulfils the BSN-role and the en. alled nurse the ADN-role However, training for enrolled nu. ses is being phased out in favour of a new single nursing qualification In the United Kingdom differentrated practice is related to the 'skull mux issue' To describe skill mix, Gibbs et al (1991) made a distunction between 'grade mix' and 'skill mix' Grade mix refers to the number of sisters, staff nurses, enrolled nurses and auxalianes required, that is, the number of staff of each grade Skall mux on the other hand refers to the skulls and expenence of staff within these grades, for example, how many years of experience does a staff nurse have in her present specialty and does she have a post basic qualıfication in that specialty (Gibbs et al 1991) The grade mix concerns a 'top-down' approach and is more likely to lead to ngid, inappropmate delivery of services The professionally led 'bottom-up' approach to skall $\mathrm{mix}$ has the potential to help cultivate and develop the new skalls that are needed to cope with rapid and multuple changes (Cowley 1993) However, in 1992 the National Health Service (NHS) Value for Money Unit's report Skill Mix in District Nursing (National Health Service Management Executive Value for Money Team 1992) was published The report recommended halving the numbers of qualified staff because, it was suggested, certain aspects of the nurses' traditional role can be carried out cost-effectively by less well-qualıfied staff (Griffiths \& Luker 1994) According to Heath (1994) this report reduces nursing to a senes of mechanistic tasks that could be counted and reallocated In this model of skill mix highly qualified, skılled clinical professionals are asked to delegate the core of their work to unskalled workers and find themselves undertakung a supervisory or management role or even being made redundant (Heath 1994)

Patient dependency measures Measures used in the United Kingdom to determine the number, but rarely the mix, of nurses required to provide the necessary care for patients are often based on patient dependency Patient dependency on the nurse has been defined as 'the extent to which the patient's level of functional capacity dictates the tome required for personal, technical, supportive and educative nursing care' (Durand 1989) This type of measurement is not seen as appropriate to determine skall mix in nursing Therefore, at a very basic level, umproved measures of skall $\mathrm{mix}$ are required in order to avoid the limitations of indicators which reflect little more than grade and qualification $\mathrm{mx}$ Given that nurses are an expensive commodity, the issue at the heart of skall $\mathrm{mux}$ from a managenal or pragmatic point of view is the need to identify those nursing tasks which require a professional qualification (usually the more technical aspects of nursing) and to allow less or unqualified people to undertake other more basic tasks (Gibbs et al 1991)

Skall $\mathrm{mix}$ is concerned with ensuring that appropriate skills are avalable to identufy and meet needs, in the most cost-effective way Three factors may be used to guide implementation of skall mix Furst, decisions about delegation to less qualified staff should relate to the predictability of the particular practice situation, rather than to the nature of the task or the label or category attached to the client or patient Second, priorities should be set and changes in practice evaluated using community nursing profiles of health needs Finally, but most importantly, client participation should be explicitly included and encouraged in the skall mix process (Cowley 1993)

In summary, the literature reviewed shows that in the USA, the Netherlands and the United Kungdom differentiation is made between at least two types of nurse based on their level of education Furthermore, in some organizations 'experience' is used to make an (extra) distunction between nurses Because of the cessation of enrolled nurse training in the United Kingdom, it seems that more attention is pard there to cost effectivity instead of professional recognition Finally, both the American and British literature showed that there are possibilities for using assistuve personnel in (community) nursing

\section{Differentiated practice: the effects on job satisfaction}

As many artucles on differentiated practice only contain points of new (Primm 1988, McClure 1991, Gibbs et al 1991, Cowley 1993, Barter \& Furmidge 1994, Heath 1994) whereas others are restricted to job descriptions (Primm 1986, 1987, Johnson 1988, Koerner 1988, Kenyon et al 1990, Hickey et al 1991, Forsey et al 1993, Wiles \& Robison 1994) only a few describe the outcomes of differentiated practice (Hersterly \& Sebilia 1986, Koerner et al 1989. Amencan Organization of Nurse Executives 1990, Malloch et al 1990, Martn \& McGure 1990, Jung et al 1994, Corley et al 1994, Hutchens 1994) The Dutch and Bnitısh literature did not yneld any information at all about the effects of differentrated practice Consequently the effects presented here only concern the American situation

The review of the hterature did not yreld extensively described methods used to measure the outcomes of 
differentiated practice systematically In two articles, only surveys measuring job satusfaction were described These instruments paid attention to pay, autonomy, task requirements, organizational policies, interaction, professional status (Koerner et al 1989, Malloch et al 1990), quality of care, enjoyment and time to do one's job (Malloch et al 1990 ) In addition to these quantitative outcomes, qualitative and anecdotal data were collected during the implementation of differentiated practice The outcomes reported in nursing literature were summanzed by Hutchens (1994) (Table 3) This summary is to a great extent based on the results of the Sioux Valley Hospital Experience

In addition to these positive effects, the Sioux Valley Hospital Experience also showed that nursing staff expressed muxed feelings about the project and the presence of two distunctly different practice roles While the

Table 3 Improved job satısfaction as a result of differentıated nursing practice reported in nursing literature

Improved job satisfaction

Higher scores on nursing satisfaction surveys

Positive anecdotal comments from nurses

Improved staff perceptions about components of work degree of challenge, task requirements, variety, opportunity to use judgement, opportunity to develop competencies Improved commitment to work

Enhanced ability to accomplish work

Improved accountability

Stabilization of nursing positions (less turnover and less difficulty filling positions)

Managerial perceptions that practitioners' professional behaviours were enhanced, including, collaboration, accountability (for clients and unit) and professional selfdevelopment

Managemal role change shift from problem solver to mentor

Source Hutchens (1994)

Table 4 Improved quality of care as a result of differentuated nursing practice reported in nursing literature

Improved quality of cere

Higher scores on client satisfaction surveys

Positive anecdotal comments from clients and famlies

Client requests to be readmitted to units that use differentiated

nursing practice models

Improved continuty in care

Improved quality assurance ratungs and trending in incident reports

Positive comments and ratungs from the surveyors of the Jount Commission of Accreditation of Healthcare Organizations

Source Hutchens (1994) case associate nurses contınue to enjoy nursing practice, some felt they had lost something because someone with another job status was practising beside them Conversely, several BSN nurses expressed a great deal of job satusfacton because they could now practice 'what they were taught in school' (Koerner et al 1989)

The clinical ladder programmes showed that the candldates recelved professional recognition from the organization and their peers as they proceeded through the program The participants individually demonstrated selfgrowth in the areas of leadership, teaching, and rolemodelling (Hesterley \& Sebila 1986, Martın \& McGuure 1990) Other results showed that, according to the staff, clinical ladders had little effect on their recruitment and retention decisions (Martin \& McGurre 1990, Corley et al 1994) A programme to establush better use of assistive personnel enabled registered nurses to delegate more patient care activities to nursing assistants After implementation registered nurses noticed a decreased workload, and increased ability to supervise assistants With respect to job satisfaction and co-ordination of care, no differences were found (Jung et al 1994)

\section{Differentiated practice: the effects on quality of care}

To describe the effects of differentrated practice the overview of Hutchens (1994) wll be presented again (Table 4)

From a patient care perspective, the participants in the clinical ladder system contributed a great deal through the continuing education programme, unit-based, in-service patient-care conferences, formalized care plans, protocol development, and quality assurance activities (Hesterly \& Sebilia 1986) After implementation of the programme with assistive personnel, registered nurses and patients noticed an improved quality of nursing care More tume and effort was being devoted to the delivery of basic physical and nutritional care This increased avallability and productivity of nursing assistant care givers may be perceived by patients as better care In addition, registered nurses had more tume to devote to the planning, co-ordination, and evaluation of patient care, which should further improve quality (Jung et al 1994)

In summary, the results described in the literature reviewed show that positive effects on job satısfaction can be expected, especially for the first level nurses As regards the quality of care, positive effects were also described However, the literature mainly contained job descriptions and considerations, whereas only a few projects studied the outcomes of differentiated practice systematically and consistently A reliable approach is needed particularly for measuring the quality of care from a client perspectrve, as it is possible that many patients are satisfied just because they are cared for and not because of the organizational principles used 


\section{Specialization: the concept and models}

Several areas of specialization are possible because the populations served by community health nurses are so diverse The study of Ruportella-Muller et al (1991) identffied population groups and health conditions considered appropriate for graduate-level community health nursing (CHN) practice and employment in the USA According to 588 leaders in CHN service and education, the population groups most in need of graduate-prepared CHNs are the elderly, persons of low socio-economic status, the homeless, adolescents, and the unemployed The health conditions most in need of CHN services are AIDS, pregnancy and prenatal problems, low birth weight and infant mortality, stress-related llness, and Alzheimer's and other chronic diseases of elderly people The findings provide the direction and justification for developing specialty options within CHN that correspond to these identufied and changing needs (Ruportella-Muller et al 1991)

The population groups and health conditions mentioned by Riportella-Muller et al (1991) are developed in the USA and United Kingdom mainly by the employment of clinical nurse specialssts (CNS) The literature reviewed showed different specialties for example patients who are HIV infected (Bond et al 1990a, 1990b, Bond et al 1991, Haste \& MacDonald 1992, Layzell \& McCarthy 1993), patients who need critical care by means of advanced technological equipment such as pumps for tube feeding and intravenous therapy, ventılators, suctioning machines, cardiac and respiratory monitors (Bowyer 1986 , Roe-Priour 1994), terminally ill (e g the Macmillan nurse) (Bergen 1991, Haste \& MacDonald 1992 , Nash 1993, Gruffiths \& Luker 1994), elderly people (Haste \& MacDonald 1992), drabetics (Kyne 1986, Moyer 1989, Griffiths \& Luker 1994), patients needing continence care or stoma care (Griffiths \& Luker 1994), patients with lung cancer (McCorkle et al 1989), and patients who need coronary care (Duddy \& Parahoo 1992)

\section{The Netherlands}

In the Netherlands specialized knowledge and sklls are avalable by both the employment of CNSs (e $\mathrm{g}$ Wregers 1992, Kiers 1993, Moons et al 1994) and by means of the construction of 'areas-of-special-expertise' for community nurses and community nurse auxilianes Areas-of-specialexpertise are constructed mainly based on patient categorles These areas are constructed where specific knowledge is needed for the caring of a particular patient category, where a lot of treatment is possible or where many changes occur in a specific category Examples of these areas are patients with AIDS, diabetics, patients with chronic nonspecific lung disease (CNSLD), patients with dementia, patents with rheumatism or patients who are incontinent Within one (or more) of these areas a community nurse (auxiliary) keeps up to date with all the new develop- ments, and attends educational programmes to stay abreast of trends and innovations on these issues

Subsequently, in her team and agency she can be consulted by her peers for knowledge or skalls In addition to this special expertise, the nurse performs the general tasks within community nursing (Ketelaars 1992, Wiegers 1992, Jansen \& Kerkstra 1993, van Haaren 1994) In 1992, almost half the Dutch agencies for community nursing had areasof-special-expertise in use, and about one third intended to construct these areas for community nurses and community nurse auxaliaries (Jansen \& Kerkstra 1993)

\section{Specialization: the effects on job satisfaction}

Because nurses who deliver direct nursing care are the subject of this paper, we pay attention to their job satusfaction in respect of specialization in community nursing According to the review of the hterature by Bergen (1991) the role of the community nurse does not seem to have diminished since the advent of specialıst nurses Community nurses (and other health professionals) generally valued the specialist service, despite the potential conflicts over responsibility for care However, two artucles pard specific attention to the community nurse's attutude to the CNS (Haste \& MacDonald 1992, Gnffiths \& Luker 1994) The results of these two studies are presented in the next paragraph

\section{Community nurse specialists in the community}

Although the work of CNSs is seen to be worthwhile, integration of specialists into the community service is not as good as it might have been Depending on the speciality. $20-50 \%$ felt that specialist nurses routunely or sometumes did work that district nurses should be doing District nurses expressed significantly more dissatisfaction than specialısts, with higher dissatisfaction scores on the factors of emotional climate, professional considerations, social significance, pay and professional preparation They also tended to be more dissatisfied with working conditions Nurses reported that they would have preferred to carry out the work of the CNSs themselves, but were prevented from doing so by heavy caseloads and lack of time

The majonty of managers and nurses appeared to agree with recommendations made in the Cumberlege Report (1986) and in the review of community nursing in Wales (Welsh Office, Department of Health 1987), that distruct nurses should develop special responsibilities for particular patient groups to combine with district nursing duties Many aspects of district nursing work are also being progressively deskulled and handed over to less qualıfied nursing staff and social services In theory, the community nurse is left with more tume to develop the specialized parts of her work, provided that work-load pressure does not increase as a consequence of NHS reorganization The desire of community nurses to become more 
knowledgeable in specialist areas 18 clear (Haste \& MacDonald 1992, Griffiths \& Luker 1994)

Because the areas-of-special-expertuse in the Netherlands are a relatively new concept, the effects on job satusfacthon have not yet been extensively studied In line with the United Kingdom literature presented above, it is expected and hoped that job satusfaction among nurses will remaun or improve when they have an area-of-special-expertise The results of the study from van Bragt (1993) only partly support this expectation In this study community nurses with an area-of-special-expertuse gauned more expertuse in that area but a heavier workload as well The nurses did not have enough time to carry out the tasks in their area

\section{Specialization: the effects on quality of care}

Extensive research into the contribution of specialist nurses to quality of care is largely absent However, in almost all the studies reviewed it is suggested that the quality of care is umproved by specialıst nurses working in community health care Some of these studies will be presented here The role of CNSs for the terminally 11 was generally highly valued by patients and particularly by carers It has probably enabled patients to spend a larger portion of their sllness at home and/or die there (Bergen 1991) Research of a complex care team showed that it had helped the patient to shorten or avoid hospitalization Furthermore, patients and their famlies expressed complete satisfaction and gratitude for the care and service offered them ( Bowyer 1986) Evaluation of a 'coronary specialıst nursing service' showed that most respondents found that information from nurses was always forthcoming, that the information received was well explained and that the amount of information was more than expected (Duddy \& Parahoo 1992)

According to several CNSs, the majority of community nurse managers felt that the introduction of specialist nurses had resulted in better patient care, improvement in distnct nurses' knowledge and better communication between hospital and community (Haste \& MacDonald 1992) Finally, specialızed AIDS home care has proved to be desurable from the perspective of the patients and therr informal and professional caregivers (Layzell \& McCarthy 1993, Moons et al 1994)

Apart from all this positive information about the CNS role, the study of Griffiths \& Luker (1994) showed that there was httle consensus among the community nurses as to whether CNSs contributed to high-quality care in the community In line with this, the studies of Christiaans et al (1993) and Wiegers (1992) showed that the use of areas-of-special-expertıse also can guarantee quality of care Christraans et al (1993) showed that community nurses with an area-of-special-expertise took better care of their relationship with the client and that the situation was better analysed when compared with community nurses without an area-of-special-expertise Wiegers (1992) showed that there were no differences with the nursing of children with chronic non-specific lung disease (CNSLD) in quality of care between CNSs and community nurses with an area-of-special-expertise This study showed that specific expenence in this area (CNSLD) effects the quality of care

In summary, it seems that there is a need for specialized expertise in community nursing In a lot of situations this is delivered by clinical nurse specialists However, community nurses are not always satisfied with a specialist working beside them and believe that they can deliver specialist care to a certain extent when they get the opportunity (e g time and training) The construction of areasof-special-expertise may be an answer to this problem With regard to the effects on the quality of care, extensive research is agaun largely absent

\section{TOWARDS A MODEL FOR EVALUATION OF DIFFERENTIATED PRACTICE AND SPECIALIZATION IN COMMUNITY NURSING}

The literature reviewed above showed that job characteristics in nursing roles will be changed in consequence of differentrated practice and specialization and can therefore affect job satisfaction and quality of care The review of the literature also showed that little quantitative information is avalable about the outcomes of differentrated practice and specialization in community nursing practice Nothing at all was found on burnout in the literature reviewed In order to study the effects of differentiated practice and specialization systematically, a research model was developed based on the previously presented Job Characteristics Model and the experience with this model in other studies Because the review of the hiterature presented above did not yeld enough information about the specific effects of $\mathrm{ob}$ and individual characteristics, research on job satisfaction and burnout was studied to find additional factors

The meta-analytic study (Blegen 1991) identified 13 var1ables that are often linked with nurses' job satisfaction In this study hospitals were the most common work sites The results of this meta-analysis indicated that job satisfaction is most strongly and negatively related with stress and positively related to commitment Autonomy, communication with supervisors, communication with peers, and recognition were moderately and positively related to job satısfaction Low negative correlations were found between job satısfaction and locus of control, whereas farrness in reward distribution was positively related Analysis of the demographic variables provided evidence for small but stable relationships between age, education and job satisfaction Nurses who were older were more satisfied and those with more educational qualifications 
were less satusfied with therr work (Blegen 1991) The study of Boumans (1990) showed that individual charactenstics were related to job satusfaction as well as job characteristics She found that nurses who had a lot of social support at work were more satisfied, whereas nurses who preferred autonomy in their work and sought distraction when they were faced with problems were less satusfied with their jobs

\section{Burnout-dimensions}

In respect of the three burnout-dimensions (emotional exhaustion, depersonalization and personal accomplishment), research among health care social workers showed that role conflict, role ambiguty, and lack of physical comfort were significantly related to emotional exhaustion Depersonalization was related to high role conflict, low challenge, and low satisfaction with financial rewards Significant job characteristics for the sense of personal accomplishment were high challenge, high workload, greater satısfaction with financial rewards, low levels of role conflict, and low levels of conflict with professional values (Siefert et al 1991) Among nurses, feelings of emotional exhaustion increased when the amount of workload increased This relation was reduced when nurses had more autonomy in their work A negative relation was found between the amount of challenge in the job and social support experienced with feelings of emotional exhaustion (de Jonge et al 1994) Individual characteristics are also related to burnout in addition to job characteristics

The study of Boyle et al (1991) showed that hardiness of personality, social support and ways of coping are related to burnout Hardy persons have a higher sense of commitment to work and self and feel a greater sense of control over their lives, viewing stressors as potential opportunities for change Social support had a negative relationship to burnout too Both work-related and nonwork-related sources of social support were significantly related to burnout With respect to coping this study showed that problem-focused coping was not related to burnout, whereas use of emotion-focused coping was pos1tively related to burnout Peer-support and support from supervisors were the two most commonly reported factors that assisted nurses in coping with job-related stressful events (Boyle et al 1991)

Last but not least it is important to study whether the effects of differentrated practice and/or specialization are the same for first level and second level nurses For example, it is conceivable that the role of a second level nurse is less attractive when differentrated practice is used Consequently the variable 'nursing role' has to be mcluded in the research model Figure 2 presents the final model for the study of the effects of differentuated practice and specialization in community nursing

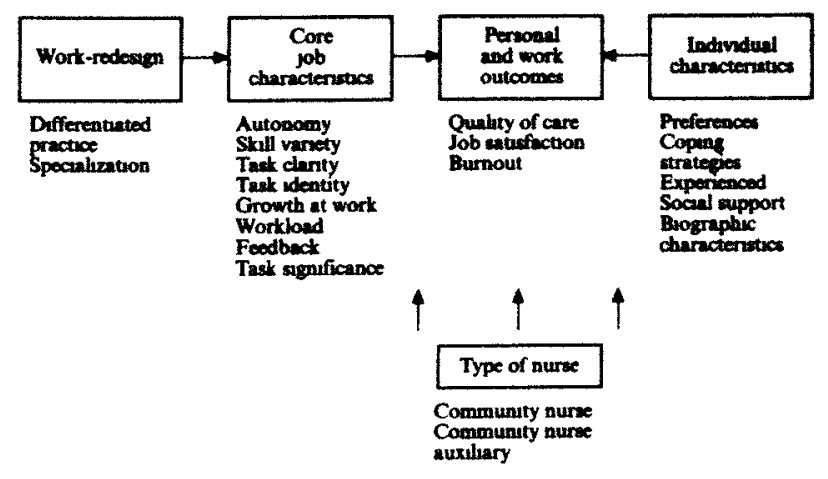

Figure 2 Model to evaluate the effects of differentiated practice and specialization in communty nursing

The research model suggests that several job characteristics will change when differentrated practice and specialization are used As a result the quality of care, job satisfaction and burnout will change Because the outcomes are also influenced by individual charactenstics, these have to be taken into account as well Finally, the outcomes will be directly influenced by the nursing role, and indirectly by moderating the relations with job and individual characteristics

\section{CONCLUSION}

In this review we have organized the literature around differentiated practice and specialization in community nursing (1 e district nursing) As regards differentiated practice, differentiation is made between at least two types of nurse based on education, complexity of care and expenence mainly Regarding specialization the review shows that specialized expertise in a lot of situations is delivered by clinical nurse specialısts (CNSs) Besides, in the Netherlands areas-of-special-expertuse are constructed to give community nurses and nurse auxilaries the opportunity to improve their specialızed knowledge

Although it can be expected that both differentiated practice and specialization have consequences for job charactenstics, and therefore affect job satısfaction, quality of care and burnout, the review did not extensively yield information about this relationship In a lot of studies only parts of the model presented in Figure 2 were studied Because another study of the authors showed that both job and individual characteristics (including the type of nurse) affect job satisfaction and burnout (Jansen \& Kerkstra 1995), it is worthwhile to study the effects of workredesign by means of the model presented Research based on this model will result in an overall impression of the effects of differentiated practice and specialization in (community) nursing 


\section{Acknowledgement}

Thus research was carried out under the auspices of the Dutch Professional Nurses Association (NU'91), section Community Nursing The study was financed by the National Centre, Nursing \& Caring (LCVV) in the Netherlands

\section{References}

Algera J A (1983) 'Objective' and perceived task characteristics as a determinant of reactions by task performers Journal of Occupational Psychology 56, 95-105

Algera J A , Fleer van der H \& Kamp van der L J Th (1986) Causal modeling of quality of work In The psychology of work and organizatıon (Debus G \& Schroiff $H$ W eds), Elsevier Science Publishers, Amsterdam, pp 175-182

American Organzation of Nurse Executives (1990) Current issues and perspectives on differentrated practice American Hospital Association, Chicago

Barter M \& Furmidge M L (1994) Unlicensed assistive personnel The Journal of Nursing Administration 24(4), 36-40

Benner P (1984) From novice to expert Addıson-Wesley, Menlo Park, Calıformia

Bergen A (1991) Nurses caring for the terminally ill in the community a review of the literature International Journal of Nursinsg Studies 28(1), 89-101

Blegen M A (1993) Nurses' job satisfaction a meta-analysis of related variables Nursing Research 42(1), 36-41

Bond S , Rhodes T , Philps P , Setters J , Foy C \& Bond J (1991) Expenence and preparation of community nursing staff for work associated with HIV infection and AIDS Social Science and Medıcine 32(1), 71-76

Bond S , Rhodes T , Philips P \& Tiemey A J (1990a) HIV infection and community nursing staff in Scotland-1, experience, practace and education Nursing Times 86(45), 47-50

Bond S , Rhodes T , Phlips P \& Tierney A J (1990b) HIV infection and community nursing staff in Scotland-2, knowledge and attutudes Nursing Times 86(45), 49-51

Boston C M (1990) Introduction In Current issues and perspectives on differentıated practice Amencan Organization of Nurse Executives, Chicago. pp 1-3

Boumans N P G (1990) Het werk van verpleegkundıge in algemene ziekenhuzen een onderzoek naar werkaspecten en hun invloed op verpleegkundigen (The work of nurses in hospitals a study about job characternstics and their effects on nurses) PhD thesis, Health Care Science, Rujksuniversiteit Limburg, Maastncht

Bowyer C K (1986) The complex care team meeting the needs of high-technology nursing at home Home Healthcare Nurse 4(1), 24-29

Boyle A , Grap M J , Younger J \& Thornby D (1991) Personality hardiness, ways of coping, social support and burnout in critical care nurses Journal of Advanced Nursing 16, 850-857

Broadbent DE (1985) The clinical impact of job design British Journal of Clincal Psychology 24, 33-44

Chrnstaans M A C, Hurkmans M H J , Hollands L \& Boumans N P G (1993) Invloed van het deskundigherdsniveau op de kwaliteit van zorgverlening in complexe verpleegsituaties (Effects of the level of expertse on the quality of care in complex nursing situatons ) Verpleegkunde 1(1), 27-37

Corcoran S A (1986) Task complexity and nursing expertise as factors in decision making Nursing Research 35(2), 107-112

Corley M C , Farley B , Geddes N, Goodloe L \& Green P (1994) The clinical ladder impact on nurse satisfaction and turnover The Journal of Nursing Administration 24(2), 42-48

Cowley S (1993) Skall mux value for whom? Health Visitor 66(5), 166-168

Cumberlege I (1986) Neighbourhood nursing - A focus for care Report of the Communty Nursing Review Her Majesty's Stationery Office, London

de Jonge J , Janssen P \& Landeweerd A (1994) Effecten van werkdruk, autonome en sociale ondersteuning op de werkbeleving van verplegenden en verzorgenden (Effects of workload, autonomy and social support on work-expenence of nurses and nurse' auxilharies ) Verpleegkunde 1, 17-26

Derckx E , Hollands L \& Halfens R (1993) Complexiteit van verpleegsituaties Een meetinstrument voor de wijkverpleging (Complexity of nursing situations A measuring instrument for community nursing) Tijdschnft voor Verpleegkundigen 24(23), 773-779

Duddy I \& Parahoo K (1992) The evaluation of a community coronary specialist nursing service in Northern Ireland Journal of Advanced Nursing 17, 288-293

Durand I (1989) Nurse/patient dependency in community nursing Nursing Times 85(5), 55-57

Fawcett J (1989) Analysis and evaluation of conceptual models of nursing F A Davis, Philadelpha

Forsey L M , Cleland V S \& Miller B (1993) Job descriptions for differentiated nursing practice and differentiated pay The Journal of Nursing Administration 23(5), 33-40

Gibbs I , McCaughan D \& Griffiths M (1991) Skıll mux in nursing a selectrve review of the hiterature Journal of Advanced Nursing 16, 242-249

Griffiths J \& Luker K (1994) Community nurse attitudes to the clinical nurse specialist Nursing Times 90(17), 39-42

Hackman J R. \& Oldham G R (1975) Development of the Job Diagnostuc Survey Journal of Apphed Psychology 60(2), 159-170

Hackman J R \& Oldham G R (1976) Motivation through the design of work test of a theory Organzational Behavior and Human Performance 16, 250-279

Hackman J R \& Oldham G R (1980) Work redesıgn AddısonWesley, Massachusetts

Hanrahan M H \& Lapré F (1990) Project wıjkzıekenverzorgenden Deskundigheden verdeeld (Project community nurse' auxiliaries Expertises divided) Landelıke Verenging voor Thusszorg, Bunnik.

Haste F H \& MacDonald L D (1992) The role of the specialıst in community nursing perceptions of specialst and district nurses International Journal of Nursing Studies 29(1), 37-47

Heath I (1994) Skall mux in primary care should be used to match services to needs rather than to cut costs British Medical Journal 308, 993-994

Hesterly S \& Sebiha A J (1986) Recognizing clinical excellence The Journal of Nursing Admunustration 16(12), 34-38

Hickey M, Billings D M, Disch J, Eagleton B , Carty Farrell M , Turzan $L$ et al (1991) Competence statements for differentrated nursing practice in critical care Focus on Critical Care 18(4), 286-293 
Hutchens GC (1994) Differentuated interdisciplinary practice The fournal of Nursing Administration 24(6), 52-58

Jansen P G M \& Kerkstra A (1993) Functiedıfferentiatie binnen de thuszorg De functies van wykverpleegkundige, wikverpleegster en gezinsverzorgende nader omschreven (Differenthated practice and specialization in communty nursing Job descriptions of communty nurses, communty nurse' auxalanes and home helps ) NIVEL, Utrecht

Jansen P G M \& Kerkstra A (1995) Effecten van functıedıfferentıatıe binnen de thuszorg (Effects of differentiated practice and specialization in community nursing) NIVEL, Utrecht, pp 49-62

Johnson J H (1988) Differences in the performances of baccalaureate, associate degree, and diploma nurses a meta-analysis Research in Nursing and Health 11, 183-197

Jung F D , Pearcey L G \& Philips J L (1994) Evaluation of a program to improve nursing assistant use The Journal of Nursing Administration 24(3), 42-47

Kenyon V, Smith E, Hefty L V , Bell M L, McNeil J \& Martaus $T$ (1990) Clinical competencies for community health nursing Public Health Nursing 7(1), 33-39

Ketelaars C (1992) Goede nazorg door gedıfferentueerde wijkverpleegkundigen (Good follow-up care by specialized communty nurses ) Maatschappelıke Gezondheidszorg 20(5), 32-34

Keuning D \& Eppink D J (1990) Management en Organısatie Theorie en Toepassing (Management and organisations Theory and Utilization ) Stenfert Kroese Uitgevers, Leiden/ Antwerpen

Kiers J (1993) Samenwerkıng wijkverpleegkundige en consulente kán ıdeaal zıjn (Co-operation between community nurse and consultant can be ideal ) Maatschappelyke Gezondherdszorg 21(7), 22-25

Koerner J E (1988) In South Dakota, nurses assess, then choose their practice level Michigan Hospitals 3, 21-24

Koerner JE (1990) The relevance of differentiated practice in today's envuronment In Current issues and perspectives on differentıated practice American Organuzation of Nurse Executives, Chicago, pp 35-51

Koerner J E , Burch Bunkers L, Nelson B \& Santema K (1989) Implementing differentiated practice the Sioux Valley hospital experience The Journal of Nursing Administration 19(2), 13-20

Kyne D (1986) The specialist role Senior Nurse 5(4), 17-18

Landeweerd J A \& Boumans NPG (1988) Work satisfaction, health, and stress a study of Dutch nurses Work and Stress 2(1), 17-26

Lapré F \& Rutten J (1989) Patıententoewyzing Eerste en tweede deskundigheidsniveau in de wi)kverpleging (Patientassignment First level and second level of expertise in community nursing ) $T_{y}$ dschrift voor Verpleegkundigen 43(11), 352-354

Layzell S \& McCarthy M (1993) Specialist or genenc communty nursing care for HIV/AIDS patients? Journal of Advanced Nursing 18, 531-537

Malloch K M, Milton D A \& Jobes MO (1990) A model for differentiated nursing practice The Journal of Nursing Administration 20(2), 20-26

Martun S D \& McGuire M (1990) A clinical ladder for the community health-care setting Journal of Community health nursing 7(4), 189-197
Maslach C \& Jackson S E (1986) MBI Maslach Burnout Inventory; manual research edition Consultung Psychologists Press, Palo Alto

McClure M L. (1991) Differentuated nursing practice concepts and consideration Nursing Outlook 38(3), 106-110

McCorkle R, Benoliel I Q, Donaldson G, Georgradou F . Mounpour C \& Goodell B (1989) A randomized clinical trial of home nursing care for lung cancer patients Cancer 64(6), 1375-1382

Mintzberg H (1983) Structure in Fives Designing the Effective Organsations Prentice Hall, Englewood Cliffs

Moons M, Kerkstra A Biewenga T (1994) Specialized home care for patients with AIDS an expenment in Rotterdam, The Netherlands Journal of Advanced Nursing 19, 1132-1140

Mostert H (1993) De complexiteit van de verpleegsituatie Op zoek naar een meetinstrument (Complexity of the nursing situation Look for a measuring instrument) Tydschnft voor Verpleegkundigen 12, 408-413

Moyer A (1989) Caring for a child with diabetes the effect of specialist nurse care on parents' needs and concerns Journal of Advanced Nursing 14, 536-545

Murphy M \& DeBeck V (1990) Myths and realities In Current issues and perspectives on differentiated practice Amencan Organization of Nurse Executives, Chicago, pp 5-16

Nash A (1993) Reasons for referral to a palliatuve nursing team Journal of Advanced Nursing 18, 707-713

Nationaal Ziekenhuisinstituut - AortA Functiedifferentiatıe binnen de intramurale verpleging (Differentiated practsce in hospitals / Nationaal Ziekenhuisinstituut - AortA, Utrecht

National Health Service Management Executive Value for Money Team (1992) The nursing skill mix in the district nursing service HMSO, London

National Councll for Health Care (1988) Verpleegkundig beroepsprofiel (Nursing profile) National Councll for Health Care, Zoetermeer

Nollen C L M (1990) Zorgkwaliteit van twee deskundigherdsnveaus binnen complexe verpleegsituations in de wykverpleging (Quality of care by two levels of expertise complex nursing situations in community nursing) MSc thesis, Nursing Science, Ruksuniversiteit Limburg, Maastricht

Prumm P L (1986) Entry into practice competency statements for BSNs and ADNs Nursing Outlook 34(3), 135-137

Primm P L (1987) Differentiated Practuce for ADN- and BSN-Prepared Nurses Journal of Professional Nursing 4, 218-225

Primm PL (1988) Implementation of differentiated practice through differentiated case management Michigan Nurse (9), 33

Primm P L (1990) Approaches and strategies In Current issues and perspectives on differentiated practice American Organization of Nurse Executives, Chicago, pp 17-34

Riportella-Muller R., Selby M L , Salmon M E , Quade D \& Legault C (1991) Specialty roles in community health nursing a national survey of educational needs Public Health Nursing 8(2), 81-89

Roberts K H \& Glick W H (1981) The job charactenstics approach to task design a critical review Journal of Applied Psychology 66, 193-217

Roe-Prior P, Watts R J \& Burke K (1994) Cnitical care clinical nurse specialist in home health care survey results Clinical Nurse Specialıst 8(1), 35-40 
Siefert K , Jayaratne S \& Chess W A (1991) Job satisfaction, burnout, and turnover in health care social workers Health and Social Work 16(3), 193-202

Soeken KL \& Prescott P A (1991) Patient intensity for nursing index the measurement model Research in Nursing and Health 14, 297-304

Turton P (1984) Nurses working in the community Nursing Times $5,40-42$

Taylor B (1985) The effects of DRGs on home health care New Jersey's experience suggests DRGs are increasing the need for home care for more acutely ill patients Nursing Outlook 33(6), 288-289

van Amelsvoort F , Slingerland P \& Verkaar E (1993) Op kwaliteit aangesproken Beslismodel voor de inzet van menskracht (Talking about quality Model of decision for staffing ) NIZW, Utrecht

van Bragt M J A B (1993) Het gedifferentieerd en allround werken bınnen de wijkverpleging Een onderzoek blj Kruswerk WestBrabant en Stichting Interkruss Noord-Kennemerland (Speciahzation and non-specialization in community nursing A study carned out at Kruswerk West-Brabant and Stichting Interkxuis Noord-Kennemerland) MSc thesis, Nursing Science, Rijksuniversiteit Lumburg, Maastricht

van Haaren E (1994) De expert Carrière maken met de handen aan het bed (The expert make a career with the hands on bed ) Maatschappelyke Gezondheidszorg 22(4), 26-28

van $T ı l$, Halfens $R$ \& Hollands $L$ (1994) Deskundig- herdsniveaus gerelateerd aan complexiteit van wykverpleegkundige zorg (Levels of expertise correlation with complexaty of nursing care ) Verpleegkunde 1, 28-38

Verhey R.A \& Kerkstra A (1992) International Compantrve Study of Community Nursing Avebury, Aldershot

Verran J A \& Reid P J (1987) Replicated testing of the nursing technology model Nursing Research 36(3), 190-194

Vrielink H (1990) Deskundigheit op maat Beleidsnota $1^{\circ}$ en $2^{\circ}$ deskundigheidsniveau (The night expertise Policy document first and second level of expertıse) Stıchting Amsterdams Kruswerk, Amsterdam

Welsh Office, Department of Health (1987) Nursing in the community a team approach for Wales Report of the review of Communty Nursing in Wales Charman, $\mathbf{N}$ Edwards Welsh Office, Cardiff

Wiegers T A (1992) Evaluatie van modellen voor aansluting tussen intramurale specialistische en extramurale verpleegkundige cara-zorg voor kinderen (Evaluation of models for connection between specialized hospital care and community nursing care for chldren with chronic non-specific lung diseases) NIVEL, Utrecht

Wijdeven C (1989) Partners op verschillend niveau (Partners on different levels) MSc thesis, Nursing Science, Ruksuniversiteit Limburg, Maastricht

Wiles R \& Robison J (1994) Teamwork in primary care the views and experiences of nurses, midwives and health visitors Journal of Advanced Nursing 20, 324-330 
This document is a scanned copy of a printed document. No warranty is given about the accuracy of the copy. Users should refer to the original published version of the material. 